DOI: $10.22616 /$ REEP.2020.047

\title{
Measurement and Analysis Issues in Research of Interrelation between Organizational Learning Culture and Organizational Citizenship Behaviour
}

\author{
Alona Eisenberg ${ }^{1}$ Dr.oec.; Jel̦ena Davidova ${ }^{2}$ Dr.paed. \\ Kiryat Bialik Municipality, Israel ${ }^{1}$; Daugavpils University, Latvia ${ }^{2}$ \\ alonaeisenberg@ hotmail.com ${ }^{1}$; jelena.davidova@du.lv²
}

\begin{abstract}
This research examined the interrelation between Organizational Learning Culture (further - OLC) and Organizational Citizenship Behaviour (further - OCB), the developed, adapted and practically approbated model for understanding the relationship between OLC and OCB. The developed model makes it possible to distinguish the factor structure of the phenomenon. This research selected dimensions of OLC (Employees Inclusion, Continuous Learning, Encouraging Leadership, Supporting System and Proactive Learning Environment), which defined the type of organization relative to its learning level (Learning Organization, Organization in Conflict, Outdated Organization and Organization in Evolution). According to OCB, in this study were selected three dimensions: Job Dedication, Civil Virtue, and Loyalty. This research classified employees according to their orientation toward their behaviour at work and found four groups that interpreted as Job orientation, Civil service orientation, Career orientation and Calling orientation. The empirical basis of the research was the data obtained from a survey of 529 respondents that were examined in 12 local authorities in Israel. The proposed methodology can be used to assess the type of organization according to OLC and classifying employees in relation to their organization to develop methods for improving the efficiency of the organization.
\end{abstract}

Keywords: organizational citizenship behaviour, organizational learning culture, learning organization.

\section{Introduction}

Organizational survival depends on their ability to learn to adapt themselves to changes in the environment. Globalization, information technology development, resource depletion, privatization, decentralization of budgets and economic crises lead to a search for new ways to increase organizational productivity, profitability, efficiency and to improve service, by finding internal resources. Under these conditions, where the speed of changes, their nature and impact are unexpected, the organization's ability to learn is critical (Pedler, 1996). In this atmosphere, it seems impossible for organizations to preserve their outdated structure and to transform them into a more flexible and adaptive organism. This new kind of organization structure should contain greater knowledge, flexibility, power, and learning ability and will be named as a 'learning organization', which has a positive impact, not only on the individuals but also on the effectiveness of the organization (Watkins, Marsick, 2003). Organizations that have prioritized learning and development achieve an increase in productivity and profitability. Creating learning processes and culture could attract, motivate and train employees and in this way cause them to invest in their work and to detect organizational involvement beyond the demands of the role. D.W. Organ (1990) called human behaviour that is expressed in the employees' contribution beyond the job's demands, beyond the level they are committed to and for what they are not recompensed by the organization as 'Organizational Citizenship Behaviour' (OCB).

This research suggests that the organization should look for ways of improving the OCB of its employees by generating an Organizational Learning Culture (OLC) motivated by the leadership. According to H.C. Pickford and G. Joy, employees who feel organizational citizenship will "go the extra mile" out of personal motivation - identifying these motivations can lead to increased performance and job satisfaction (Pickford, Joy, 2016, 1).

The aim of this research is developing a structural model the interrelation between OCB and OLC, analysing their factors and providing the practical tools for monitoring OLC, it's classifying and OCB behaviour of the employees the purpose of increasing efficiency by correcting that behaviour.

The learning organizational indices OCB can be used by the manager as evaluation tools to determine employees' levels of performance. These indices would help to identify an organization whose employees express willingness to maintain an OCB beyond the requirement in the formal role framework. This may 
help to recognize the degree of success of the organization in fulfilling its objectives and especially the employees' attitude towards the organizational apparatus.

\section{Methodology \\ Participants and procedure}

The empirical basis of the research was the data obtained from a survey of 529 respondents from 12 local authorities in Israel. Local government has chosen to allow diversity in terms of geographical location, size, type, socioeconomic cluster, etc. The respondents were from all types of local government: municipalities, local and regional councils, from all places in the country: North, Central, and Southern, from all sizes of cities: small, medium and large, and from all types of socioeconomic status. In order to maintain anonymity, the local authorities participating in the study were given a code.

The majority of respondents 348 (65.8\%) were women, 181 respondents (34.2\%) were men. According to the number of employees in the organization, it is possible to learn that in four local authorities participating in the study, the number of employees is up to 200 , which is $33 \%$; in three local authorities, the number of employees is 300-500, which is $25 \%$; in two local authorities 600-800 (16\%) and three local authorities over 1000 employees $(25 \%)$. The study provided representation for a variety of local authorities in terms of the number of employees. By level of education, the respondents were distributed as follows: 201 respondents had a bachelor's degree (BA) representing $38 \%$ of the sample; 100 respondents had a master's degree (MA) representing $18.9 \%$ of the sample; 228 respondents had matriculation certificate representing $43.1 \%$. According to time job, the absolute majority of employees were employed full-time job: 490 respondents worked full time $(92.6 \%)$ and 39 respondents worked part-time representing $7.4 \%$ of the sample. The age of respondents varied from 24 to 72 years and half of the respondents were at least 45 years old. The average age was 45 years. The employment time of respondents varied from two months to 45 years, with an average of 13 years. A quarter of respondents had no more than five years, while the other quarter had not less than 20 years.

\section{Measures}

Data were collected through a questionnaire which contained three parts: questions for measuring the OLC, questions for measuring civic behaviour in the organization and socio-demographic details.

Independent variable: Organizational Learning Culture - OLC. Research questionnaire is based on existing questionnaire that developed by V.J. Marsick and K.E. Watkins (2003). It has been modified and adapted to suit the target population. This questionnaire's part was designed to examine the existing processes in the local government in Israel to create an organizational learning culture.

The dependent variable: Organizational Civil Behaviour - OCB. This questionnaire's part was designed to examine the existing discretionary behaviour directed at individuals or at the organization as a whole, which goes beyond existing role expectations and benefits the organization is intended to benefit it. Participants were asked to evaluate how well the description matches the reality of their behaviours. The study questionnaire is comprised of questions based on items from the study of P.M. Podsakoff (Podsakoff et al., 1990) and E. Vigoda-Gadot (Vigoda-Gadot et al., 2007). The questionnaire has a high construct validity (evaluated by confirmatory factor analysis), and each of the five sub-scales indicates good internal consistency (KMO is 0.839 , Sig. of Bartlett's Test of Sphericity $<0.001$, the lowest value of Cronbach alpha is 0.789 ). The questionnaire has been tested and modified through this research studies.

\section{Data analysis}

In order to classify respondents and organizations in the space of the identified factors, a two-stage cluster analysis was carried out: clusters allocated in the OCB factor space allow respondents to be classified according to their relation to work in the organization and clusters allocated in the space of OLC factors allow classifying organizations by the level and structure of OLC. For the analysis of the relationship between the phenomena studied, a correlation-regression analysis was used. Since the nature of the distribution of factors identified as a result of factor analysis is significantly different from normal, the Pearson Correlation coefficient was used to calculate the correlations. To prove the hypotheses, one-way analysis of variance, two-factor analysis of variance, and chi-square test were used. 


\section{Results}

\section{Organizational learning culture}

Organizational learning only exists if specific organizational cultural conditions enable it (Sampe, 2012). Human capital is depended on learning organization culture and organizational learning process. Without such a culture supporting learning in the organization, the efforts invested in individual learning and development will not bring the desired results (Joo, Yang, 2007). Organizational learning culture provides rules for sharing information, determining consents and acting ways. Organizational learning culture fosters learning, allows time to devote to tasks, encourages participation in team meetings and forums to share knowledge and ideas and motivates employees to share and develop knowledge with others.

M.N. Moghadam, M. Beheshtifar and M.A. Darvishzade (2012) argue that organizational learning culture is a building where employees are encouraged to train their initiatives and where individuals take personal possession in their learning and development at all levels within the organization. The goal of an organizational learning culture is an exchange of knowledge leading to innovation, improved performance, sustained competitiveness and survival for years (López, Peón, Ordás, 2005). A.K. Yeung (Yeung et al., 1999) claimed that a learning culture promotes knowledge acquisition and sharing, reciprocity, experimentation, risk-taking, and recognition of the opportunities created by change. Organizational learning culture is one of the main components related to organizational commitment and intrinsic motivation (Moghadam, Beheshtifar, Darvishzade, 2012). A learning culture is an integral part of organizational behaviour that occurs as a continuous process of improvement. A. Eisenberg, S. Ignatjeva, D. Iliško and A. Rauckiene-Michaelsson (2018) proposed five dimensions theory of the learning organization culture, which are associated with people and organizational structure (Table 1).

Table 1

\section{Organizational Learning Culture dimensions}

\begin{tabular}{ll}
\hline \multicolumn{1}{c}{ Dimension } & \multicolumn{1}{c}{ Definition } \\
\hline $\begin{array}{l}\text { Employees } \\
\text { Inclusion }\end{array}$ & $\begin{array}{l}\text { A cultural process that includes the employees of the organization makes them a part of the } \\
\text { organizational decision making at all levels and motivates them to contribute to the organization } \\
\text { needs and vision. }\end{array}$ \\
\hline $\begin{array}{l}\text { Continuous } \\
\text { Learning }\end{array}$ & $\begin{array}{l}\text { Continuous learning is a consistent process of sharing knowledge, experience, and skills and } \\
\text { applying them to building new behaviours for the benefit of the entire organization. }\end{array}$ \\
$\begin{array}{l}\text { Encouraging } \\
\text { Leadership }\end{array}$ & $\begin{array}{l}\text { Managerial means that encourages and supports employees to take proactive actions towards } \\
\text { achieving the goals and vision of the organization. It focuses on the individual's strength and } \\
\text { contributions in order to drive employee motivation and performance to a higher level. }\end{array}$ \\
\hline $\begin{array}{l}\text { Supporting } \\
\text { System }\end{array}$ & $\begin{array}{l}\text { An organizational environment that provides all necessary tools both in the organizational and the } \\
\text { managerial domain in order for the employees to have all needed infrastructure for continuous } \\
\text { learning. }\end{array}$ \\
\hline $\begin{array}{l}\text { Proactive } \\
\text { Learning } \\
\text { Environment }\end{array}$ & $\begin{array}{l}\text { An organizational capability providing the employees with all technical and motivational means that } \\
\text { encourages learning. The most significant role of proactive learning environment is to construct } \\
\text { a learning ability, which enables anyone to learn anyplace at any time. }\end{array}$ \\
\hline
\end{tabular}

Source: adapted from (Eisenberg, Ignatjeva, Iliško, Rauckiene-Michaelsson, 2018).

V.J. Marsick and K.E. Watkins (2003) think that a learning process is existing at two levels: learning at the individual level and learning at the organizational level; a) individual learning is related to organizational learning though not equal to it and $b$ ) organizational culture is built by leaders and other key people, who learn from their experience, influence the learning of others, and create a learning environment. According to A. Kleiner (Kleiner et al., 1994, 36), "without theory, method and tools people cannot develop the new skills and capability required for deep learning". It means that, if organizations involve employees in career development activities, it will increase their level of commitment, and satisfaction that encourages performance improvement stay in the organization, accomplishing organizational objectives efficiently (Ababneh, 2013). The organizational learning process is an important strategic tool for the organization's management to increase the involvement and contribution of the organization's employees to its goals, to increase efficiency, productivity and service quality. 
'Organizational Citizenship Behaviour' - OCB was first described by S.A. Smith (Smith, Organ, Near, 1983), who defined the behaviours that go beyond the job's demands, beyond the level is committed. According to D.W. Organ, OCB reflects "individual behaviour that is discretionary, not directly or explicitly recognized by the formal reward system and that is the aggregate which promotes the effective functioning of the organization" (Organ, 1988, 4). OCB has been identified as an important indicator of employees' performance that goes beyond formal duties and has a major positive impact on long-range sustainability, organizational outcomes, effectiveness and service quality (Podsakoff, Ahearne, MacKenzie, 1997; Vigoda-Gadot et al., 2007; Pickford, Joy, 2016). OCB does not appear in any job definition. It is the result of the personal effort of employees (Kaya, 2015). Moreover, what is expected of the employee nowadays is undergoing changes: in order to learn new technologies and to work with it, the employees require new skills and need to be more creative and competent (Eisenberg, Davidova, Kokina, 2018).

T.S. Bateman and D.W. Organ (1983) graded OCB as participating in the elective meetings, helping voluntarily other employees, providing innovative suggestions to improve the organization, avoiding complaints, not taking advantage of employees' rights, and not requesting unnecessary leaves. I. Oplatka (2009) refers OCB to several elements: voluntary, beyond what is required, formal task behaviours, behaviours based on personal choice, behaviours directed towards others or the organization and avoidance of behaviours that are harmful to the organization. According to A. Eisenberg and S. Ignatjeva (2018), organizational citizenship behaviour has three dimensions: Job Dedication, Civic Virtue and Loyalty (Table 2).

Table 2

Organizational Citizenship Behaviour dimensions

\begin{tabular}{ll}
\hline \multicolumn{1}{c}{ Dimension } & \multicolumn{1}{c}{ Definition } \\
\hline Job Dedication & $\begin{array}{l}\text { An employee behaviour focusses on hard-working, performing according to procedures } \\
\text { and rules, taking the initiative to solve a problem. }\end{array}$ \\
\hline Civil Virtue & $\begin{array}{l}\text { An employee behaviour expresses willingness to participate actively in the life of the } \\
\text { organization, to maintain and improve it. }\end{array}$ \\
\hline Loyalty & $\begin{array}{l}\text { An employee behaviour which places an organizational interest above the personal, } \\
\text { maintains an organizational interest, and identifies with the organization. }\end{array}$ \\
\hline
\end{tabular}

Source: adapted from (Eisenberg, Ignatjeva, 2018).

In the early years of the researches in this field, the studies focused on assessing behaviour at the individual level. To date, more researchers focus not only on individual level but on a group or team level and even system level of OCB (Somech, Drach-Zahavy, 2004; Vigoda-Gadot et al., 2007; Lai, Lam, Lam, 2013).

Recent studies deal with the practical aspect of OCB. According to D.W. Organ, P.M. Podsakoff, S.B. MacKenzie (2006), OCB contributes to innovation, pooling resources and adaptation to a changing and complex environment, which ultimately improves the efficiency of the entire organization. H. Qureshi (2015) supposes that OCB reinforces co-worker and manager productivity, free up resources for more productive purposes, help in coordinating action across workgroups, attract best employees to the organization, increase the stability of the organization's performance, and enable the organization to adapt effectively to environmental changes.

OCB research has primarily involved private sector businesses, traditional fields like human resource management and marketing. Few studies have examined this behaviour in the public sector, particularly in local authorities. In the public sector, it is more difficult to check OCB results because the final outcome is a service rather than a product.

For the analytic framework of OCB, this research used the three-category model of A. Eisenberg and S. Ignatjeva (2018). The operative definition for OCB for this study is a voluntary behaviour of the employee directed to the entire organization or to certain individuals, through which the employee expresses his readiness to perform his duties beyond the requirements of the official position and workplace. 


\section{The interrelation between $O L C$ and $O C B$}

Many researchers (O’Reilly, Chatman, 1996; Wayne, Shore, Liden, 1997; Jo, Joo, 2011; Islam et al., 2013; Lai, Lam, Lam, 2013; Kaya, 2015; Salas-Vallina, Alegre, Fernández, 2016; Kim, Watkins, Lu, 2017) have assumed that supportive organizational culture motivates employees to perform their job tasks beyond the required. In an organization where employees believe that this is a place where they can grow, learn, share ideas, participate in dialogue and decision making, where they can learn from mistakes without being accused, the employees will be willing to invest in their work beyond their duty. If the organization has a strong learning culture, it affects a strong motivational basis for personal activities, including employees' decisions to become engaged in prosocial activities such as OCB. The OCB dimension is not based on measuring objective economic outcomes, but it increases outputs in terms of 'service'. OCB is expressed in various levels of identification with the organization, its goals, and values. Its importance is particularly emphasized in public systems since contact with civilians often requires action beyond the definition in the formal guidelines of the position.

This research examined the concept of OLC and OCB as a context-related consequence from a multidimensional view. The present study contributes to the literature the relative effects of OLC on the emergence of OCB across Israeli municipality employees. Since studies suggest that the creation of an organizational learning culture may change and affect employee behaviour, OLC is the independent variable and OCB is a dependent variable. For the purposes of this study, organizational learning culture was described by both the structural and process dimensions of learning within an organizational context. The independent variable OLC is based on study of A. Eisenberg, S. Ignatjeva, D. Iliško and A. Rauckiene-Michaelsson (2018) that statement a multi-dimensional concept of OLC. It is described by five factors refers to learning processes at all levels of the organization: employees inclusion, continuous learning that includes sharing of knowledge, assimilation of new technologies and the participation of employees in decision-making processes, creating a supporting system, proactive learning environment and encouraging leadership.

The dependent variable OCB is based on the three-category model of A. Eisenberg and S. Ignatjeva (2018) that statement a multi-dimensional concept of citizenship behaviour. OCB refers to voluntary behaviour focuses on hard-working, performing according to procedures and rules, taking the initiative to solve a problem, active participation in the social life of the organization, setting an organizational interest above the personal. Structural model based on research of A. Eisenberg (2019) is determining the basic dimensions of both independent and dependent variables (Figure 1).

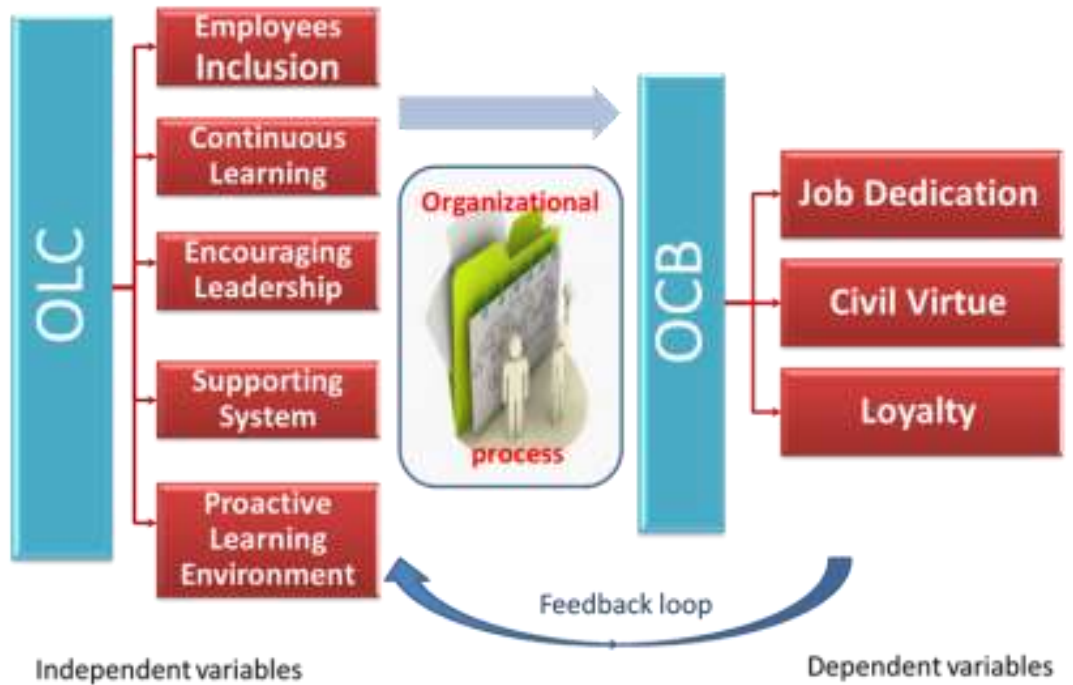

Figure 1. Structural Model of the Interrelation between OLC and OCB.

As is obvious from the structural model of research, basic dimensions of OLC as an independent variable encompass promoting Employees Inclusion, creating Continuous Learning opportunities, providing Encouraging Leadership, creating Supporting Systems to capture and share learning, establishing a Proactive Learning Environment. Basic dimensions of OCB encompass Job Dedication, Civic Virtue and Loyalty. 


\section{Cluster analysis in the space of OLC factors}

Two-stage cluster analysis in the space of OLC factors allowed allocating four homogeneous clusters (OLC Cluster Group) according to the respondents' assessment of their organization into concerning to OLC phenomenon. Four types of organizations were found relative to their learning level. Selected factors can be interpreted as a Learning Organization, Organization in Conflict, Outdated Organization and Organization in Evolution (Table 3).

Table 3

Type of organizations according to OLC

\begin{tabular}{ll}
\hline Dimension & \multicolumn{1}{c}{ Definition } \\
\hline $\begin{array}{l}\text { Learning } \\
\text { Organization }\end{array}$ & $\begin{array}{l}\text { An organization with constant learning and improvement orientation. The organization and the } \\
\text { management provide all the technical and motivational means to connect the employees to the } \\
\text { organizational goals and objectives, a process ending with improvement resulting from constant } \\
\text { learning. The organization develops learning tools such as information technologies IT, training, } \\
\text { sharing and knowledge transfer and 'organizational memory'. Management encourages employees } \\
\text { to improve and learn, by providing the time and resources required, and by encouraging and } \\
\text { rewarding success. }\end{array}$ \\
\hline $\begin{array}{l}\text { Organization } \\
\text { in Conflict }\end{array}$ & $\begin{array}{l}\text { An organization that has long been stagnant although the management is constantly trying } \\
\text { (apparently unsuccessfully) to introduce methods of learning and improvement. The organization } \\
\text { does not have the tools to enable a learning and constant improvement environment. There are } \\
\text { no mechanisms for preservation and sharing of knowledge. Employees are indifferent and do } \\
\text { only what is required from them. }\end{array}$ \\
\hline $\begin{array}{l}\text { Outdated } \\
\text { Organization }\end{array}$ & $\begin{array}{l}\text { An organization without motivation to improve and study both at the managerial level and at the } \\
\text { employee level. A manager wants only that employees do what is required of them without initiating } \\
\text { change and improvement, without learning and transferring knowledge, without developing tools } \\
\text { and providing learning systems. An organization is very reminiscent of the industrial revolution - } \\
\text { people are part of a machine - everyone has a role and must not deviate from it. }\end{array}$ \\
\hline $\begin{array}{l}\text { Organization } \\
\text { in Evolution }\end{array}$ & $\begin{array}{l}\text { An organization in a positive process of learning and improvement. The manager, the } \\
\text { employees, and the stimulating organizational factors act as a strong vector of learning and } \\
\text { improvement. However, the organizational tools that support this have not yet been developed } \\
\text { and constitute a barrier to turning the organization into a classic learning organization. }\end{array}$ \\
\hline
\end{tabular}

Source: elaborated by the authors

As a result of factor analysis, aggregated estimates of factors have a standardized form (measured on a z scale). Standardized values of factors allow classifying respondents for each of the factors, depending on whether they are above or below the average. To convert the z-estimates, the following formula was determined: $\mathrm{z}_{1}=\mathrm{M}+\sigma_{\mathrm{z}}, \mathrm{M}$ is the new arithmetic mean; $\sigma$ is the new standard deviation. In this paper, a transformation was used that translates the values of $\mathrm{z}$ into a one hundred-point $\mathrm{T}$-scale using the following formula: $\mathrm{T}=50+10 \mathrm{z}$. Estimates of factors on this scale can be interpreted as indicators of the corresponding parameters of the investigated phenomena, expressed in $\%$ in relation to the maximum possible result. The value of 50 points corresponds to the average value and can be interpreted as the level of formation of the corresponding factor by 50\%. In this case, the values from 40 to 60 points are interpreted as the average level, less than 40 - a level below average, more than 60 - a level above average.

Figure 2 shows average standardized values of OLC factors for respondents of different cluster groups. In the case of a Learning Organization cluster, all factors are in the average level, but all of them are above 50 and Proactive Learning Environment factor is very close to level above average (59.17). In the case of an Organization in Conflict cluster, Continuous Learning factor is in the level below average (38.63) and only the factor of Encouraging Leadership is above others (55.78), but still in the average level.

In the Outdated Organization cluster, the lowest factor is Encouraging Leadership (39.63) when other factors are lower than 50 and only Proactive Learning Environment is 50.25, but still low. In the Organization in Evolution, all of the factors are above 50 and only Proactive Learning Environment factor is below 50 and close to the level below average (40.98).

The respondents in the Organization in Conflict cluster are characterized by a significantly low factor Continuous Learning: lower than average for the aggregate level and lower than for respondents from 
other cluster groups. At the same time, the values of the Encouraging Leadership factor are higher than the aggregate average (the only one among the factors in this cluster) and then respondents of other cluster groups. They also have a Supporting System factor lower than the average for the aggregate and lower than for respondents from other cluster groups.

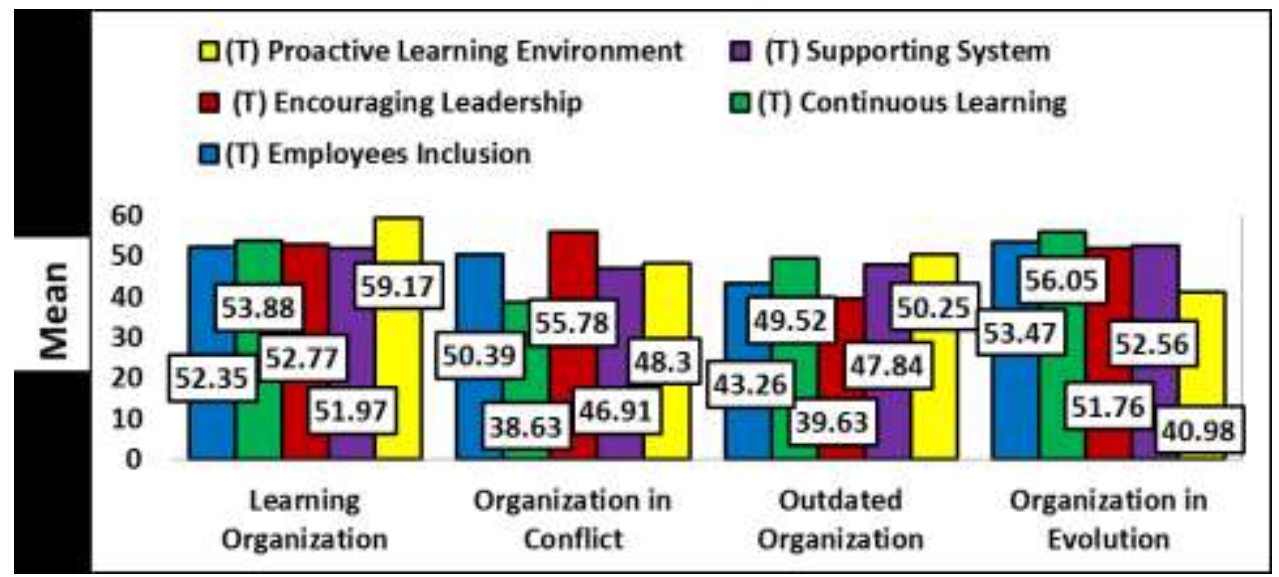

Figure 2. Average values of standardized indicators of OLC factors

among respondents from different OLC Cluster Group.

Source: elaborated by the author according to statistical data analysis in SPSS

The respondents of Outdated Organization cluster are characterized by the lowest indicators for Employees Inclusion and Encouraging Leadership, lower than the aggregate average, lower than the value of this factor in the other cluster groups. All factors except Proactive Learning Environment are lower than the aggregate average, but its value also exceeds the average slightly (50.25). The lowest average values in this cluster belong to Encouraging Leadership (39.63) and Employees Inclusion (43.26).

For respondents in Organization in Evolution cluster, the mean values of all factors except Proactive Learning Environment are higher than the than aggregate average, and the average value of the factor Continuous Learning is higher than that of respondents from other cluster groups. According to the results of a Single Factor Analysis of Variance (ANOVA), OLC factors in respondents of different OLC cluster group differ statistically significantly (Table 4).

Table 4

OLC ANOVA results

\begin{tabular}{lll}
\hline OLC & F & Sig. \\
\hline (Z) Employees Inclusion & 32.458 & 0.000 \\
(Z) Continuous Learning & 128.107 & 0.000 \\
(Z) Encouraging Leadership & 100.311 & 0.000 \\
(Z) Supporting System & 11.213 & 0.000 \\
(Z) Proactive Learning Environment & 144.180 & 0.000 \\
\hline
\end{tabular}

Source: elaborated by the author according to statistical data analysis in SPSS.

\section{Cluster analysis in the space of $O C B$ factors}

Two-stage cluster analysis in the space of OCB factors allowed grouping the respondents into homogeneous clusters. Cluster analysis in the space of OCB allows respondents to be classified according to employee relation toward their behaviour at work. Four types of behaviour were found relative to OCB. A. Wrzesniewski proposed three distinct work attitudes that people have: Job Orientation, Career Orientation and a Calling Orientation (Wrzesniewski et al., 1997). This study found one more: a Civil Service Orientation. Selected factors can be interpreted as Job Orientation, Civil Service Orientation, Career Orientation and Calling Orientation (Table 5).

Figure 3 shows average standardized values of OCB factors for respondents of different cluster groups. In the Job Orientation cluster, the lowest factor is Job Dedication (32.67) that is in level below average; when other factors are in the Average level, but they are lower than 50. 


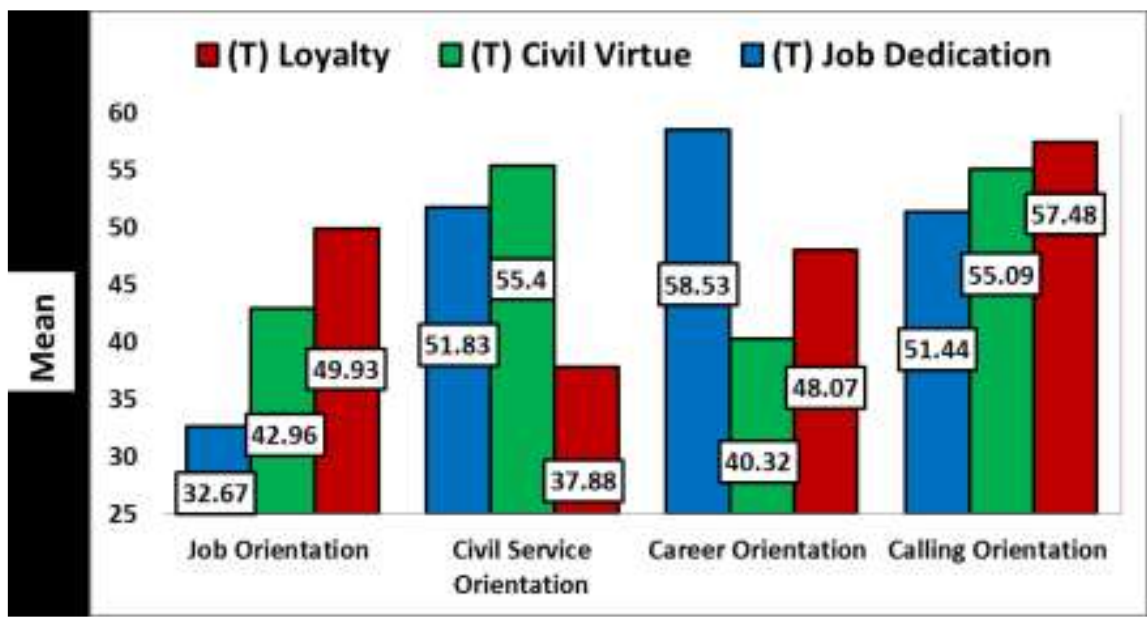

Figure 3. Average values of standardized indicators of OCB factors among respondents from different OCB Cluster Group.

Source: elaborated by the authors according to statistical data analysis in SPSS.

In the Civil Service Orientation cluster, the lowest factor is Loyalty (37.88) that is in level below average, when Job Dedication and Civil Virtue are in the average level and higher than 50. In Career Orientation cluster all factors are in the average level with the lowest factor is Civil Virtue (40.32) and highest is Job Dedication (58.53). In the Calling Orientation cluster, all of the factors are above 50 but still in the average level.

Table 5

Type of employees according to OCB

\begin{tabular}{ll}
\hline Dimension & \multicolumn{1}{c}{ Definition } \\
\hline $\begin{array}{l}\text { Job } \\
\text { Orientation }\end{array}$ & $\begin{array}{l}\text { Employees focus on financial rewards. For them, a job is not a major part of life. These people } \\
\text { work because they have to. They work to receive the pay to support their life outside of work. } \\
\text { They don't have a strong connection to the workplace or their job duties. }\end{array}$ \\
\hline $\begin{array}{l}\text { Civil Service } \\
\text { Orientation }\end{array}$ & $\begin{array}{l}\text { Employees who do not target one organization or another. They will make efforts to provide } \\
\text { service and assistance regardless of affiliation to the organization. They will try their best to help } \\
\text { their co-workers, suppliers and customers, but they will do so in any organization where they } \\
\text { work. }\end{array}$ \\
\hline $\begin{array}{l}\text { Career } \\
\text { Orientation }\end{array}$ & $\begin{array}{l}\text { Employees are ambitious people. They expect to be promoted as a reward for their work. They } \\
\text { are willing to work hard, perform the tasks, and try to impress others. They seek to reach a higher } \\
\text { status, to receive power and influence. Usually, they are mission oriented and not people and are } \\
\text { unwilling to invest in helping others. }\end{array}$ \\
\hline Calling & $\begin{array}{l}\text { Employees see their work as integral to their lives and their identity. They view their career as } \\
\text { a form of self-expression. Those people find meaning, purpose and satisfaction in their work. }\end{array}$ \\
\hline
\end{tabular}

Source: elaborated by the author and adapted from (Wrzesniewski et al., 1997; Berg, Grant, Johnson, 2010; Uygur, Koç, 2010).

Respondents with OCB Job Orientation cluster values of all OCB factors do not exceed the average for the aggregate level. Job Dedication is the lowest value of this factor in all cluster groups. The Civil Virtue factor in the Job Orientation cluster had an average of 42.96, which is lower than the aggregate average, but higher than in the Career Orientation cluster, where the average value of this factor is only 40.32 points. Respondents with OCB Civil Service Orientation cluster are characterized by the fact that the Loyalty factor they have lower than the average for the aggregate and lower than for respondents from other cluster groups. At the same time, the values of the factors Job Dedication and Civil Virtue are higher than the aggregate average. For respondents with OCB Career orientation cluster is characterized by the highest indicator of Job Dedication, while the average values of the factors of Civil Virtue and Loyalty are lower than the average for the aggregate, and the average factor Civil Virtue is lower than in the other cluster groups. The values of the Job Dedication factor have the smallest variation with respect to other factors and relative to other cluster groups. In OCB Calling Orientation cluster's respondents, the average values of all factors are higher than the average for the aggregate, and the average value of the Loyalty factor is higher than that of respondents from other cluster groups. 
According to the results of ANOVA, OCB factors in respondents of different OCB Cluster Group differ statistically significantly (Table 6). The exception is Loyalty factor in Job Orientation cluster and Career Orientation cluster. According to the Bonferroni criterion, these differences are not statistically significant (Multiple Comparisons, Bonferroni test, Sig. $=0.318$ ).

Table 6

OCB ANOVA results

\begin{tabular}{lrc}
\hline \multicolumn{1}{c}{ OCB } & F & \multicolumn{1}{c}{ Sig. } \\
\hline (T) Job Dedication & 342.271 & 0.000 \\
(T) Civil virtue & 144.097 & 0.000 \\
(T) Loyalty & 216.513 & 0.000 \\
\hline
\end{tabular}

Source: elaborated by the author according to statistical data analysis in SPSS.

\section{Demographic variables}

In order to examine the effects of demographic characteristics on OCB and OLC, these items were treated as potential control variables (age, gender, education level, and employment time) in this research. The OLC and OCB Cluster groups were examined according to their geographical location, according to the size of the municipality and belonging to a particular type of local government. According to Chi-Square Tests, demographic variables were found as statistically insignificant. Only one test was found statistical significance: the respondents with Civil Service Orientation and Calling Orientation have average age higher than the respondents with Job and Career Orientation. The respondents who see themselves as Civil Service Orientation have the largest average age $(M=46.81)$, the smallest mean age $(M=41.21)$ is observed in the Job Orientation cluster. According to ANOVA those differences are statistically significant $(F=5.772$, Sig $=0.001)$.

\section{Hypotheses testing}

To test the hypothesis and predicted relationships, analysis of regression coefficients and coefficients of multiple correlations were conducted. Direct significant correlations are observed between some of OCB and OLC factors. The Civil Virtue factor correlates with all OLC factors. The closest relationship is observed with the Supporting System factor $(r=0.355)$. The Job Dedication factor is related to the factors of Employees Inclusion, Continuous Learning, and Encouraging Leadership. The Loyalty factor is the least dependent on OLC factors: weak connections are observed with the Employees Inclusion factor and with Continuous Learning (Table 7).

Table 7

Correlation relationship between OCB and OLC factors

\begin{tabular}{llccc}
\hline & & $\begin{array}{c}\text { (T) Job } \\
\text { Dedication }\end{array}$ & $\begin{array}{c}\text { (T) Civil } \\
\text { Virtue }\end{array}$ & (T) Loyalty \\
\hline (T) Employees Inclusion & Pearson Correlation & $\mathbf{0 . 1 5 8}$ & $\mathbf{0 . 2 1 5}$ & $\mathbf{0 . 1 0 7}$ \\
& Sig. (2-tailed) & $<\mathbf{0 . 0 0 1}$ & $<\mathbf{0 . 0 0 1}$ & $\mathbf{0 . 0 1 3}$ \\
(T) Continuous Learning & Pearson Correlation & 0.157 & $\mathbf{0 . 2 9 8}$ & 0.086 \\
& Sig. (2-tailed) & $<\mathbf{0 . 0 0 1}$ & $<\mathbf{0 . 0 0 1}$ & $\mathbf{0 . 0 4 9}$ \\
(T) Encouraging & Pearson Correlation & $\mathbf{0 . 2 0 0}$ & $\mathbf{0 . 1 8 7}$ & 0.059 \\
Leadership & Sig. (2-tailed) & $<\mathbf{0 . 0 0 1}$ & $<\mathbf{0 . 0 0 1}$ & 0.175 \\
(T) Supporting System & Pearson Correlation & 0.005 & $\mathbf{0 . 3 5 5}$ & 0.021 \\
& Sig. (2-tailed) & 0.900 & $<\mathbf{0 . 0 0 1}$ & 0.628 \\
(T) Proactive Learning & Pearson Correlation & 0.038 & $\mathbf{0 . 1 5 4}$ & 0.016 \\
Environment & Sig. (2-tailed) & 0.385 & $<\mathbf{0 . 0 0 1}$ & 0.706 \\
\hline
\end{tabular}

Source: elaborated by the author according to statistical data analysis in SPSS

Analysis of regression coefficients and coefficients of multiple correlations allows drawing the following conclusions: 
- the most sensitive to the effects of OLC factors is the Civil Virtue factor; its value by $32 \%$ is determined by the combined effect of OLC factors; at the same time, the strongest influence on Civil Virtue is provided by the Supporting System factor;

- the least sensitive to the effects of OLC factors is the Loyalty;

- the Job Dedication factor is influenced only by OLC factors such as Employees Inclusion, Continuous Learning and Encouraging Leadership.

In organizations of type Learning organization and Organization in Evolution three OCB factors as Job Dedication, Civil Virtue and Loyalty exceed the average for the aggregate level. The differences between the average values of OCB factors between those two clusters are small. In organizations of type Organization in Conflict and Outdated Organization, all OCB factors do not exceed the average for the aggregate level.

The statistical analysis method of Cross-tabulation was carried out. According to it in Learning Organizations, the majority of respondents belongs to Calling Orientation $(52.67 \%)$ or to Civil Service Orientation ( $28 \%$ ) which together account for over $80.67 \%$ of the total population. Only $6.67 \%$ belong to Job Orientation and $12.67 \%$ Career Orientation. A similar image can be seen in the Organization in Evolution: $55.97 \%$ are Calling Orientation, 22.39 Civil Service Orientation that together constitute $78.36 \%$. The percent of respondents belong to Job Orientation even smaller than in Calling Orientation and constitutes $3.73 \%$. In the Outdated Organization, the greater weight is given to Job Orientation and Career Orientation (32.03\% and $29.69 \%$ ), that together constitutes $61.72 \%$ of total respondents. In this Cluster, Calling Orientation is $21.09 \%$ and Civil Service Orientation is $17.19 \%$ only. Job Orientation and Career Orientation $(25.64 \%$ and $28.21 \%)$ in the Organization in Conflict constitute $53.85 \%$. According to the $\chi^{2}$ chi-criterion the difference is statistically significant $(\mathrm{p}<0.001)$.

\section{Discussion}

This research defined OLC and OCB as multifactorial phenomena and their perception are multidimensional. According to the empirical research and statistical analysis of its results, a Model of the Interrelation between $O L C$ and $O C B$ has been developed. Four types of organizations were found: Learning Organization, Organization in Conflict, Outdated Organization and Organization in Evolution.

In a Learning Organization, Continuous Learning processes make employees more involved, more identified with the organization and its goals, part of the process of decision making and problemsolving. The respondents in the Organization in Conflict cluster are characterized by a significantly low factor of Continuous Learning and Supporting System: lower than for respondents from other cluster groups. At the same time, the values of the Encouraging Leadership factor are higher than respondents of other cluster groups. Because the Organization in Conflict it is an organization that has long been stagnant, employees are indifferent and inert, perform the minimum required, oppose any change, and especially oppose the administration's attempts to introduce new methods of learning since they do not believe in and rely on the managers. Outdated Organization cluster respondents were characterized by the lowest indicators for Employees Inclusion and Encouraging Leadership, lower than the value of this factor in the other cluster groups. It is an archaic organization without motivation to improve and learn both at the managerial level and at the employee level. Nowadays such an organization cannot survive for a long period, sophisticated employees will not join it and eventually, the clients will 'vote with the feet'. Values of Organization in Evolution are very similar to the values of different factors for a Learning Organization, with the exception of values of a Proactive Learning Environment that is the lowest value among all the clusters. In a paired correlation analysis, the correlation between Encouraging Leadership and Proactive Learning Environment is direct and significant, that is, the larger the value Encouraging Leadership, the higher the value of Proactive Learning. It means that in such type of organization, the tools that support learning processes have not yet been developed enough and constitute a barrier to turning the organization into a classic Learning Organization. This is a classic stage to involve an organizational consultant with expertise in organizational learning methodology and tools. Cluster analysis allowed finding four types of employees: with Job Orientation, Civil Service Orientation, Career Orientation, and Calling Orientation.

Job Dedication factor in Job Orientation cluster has the lowest value of this factor in all cluster groups. Such employees work because they have to. It was found a weak inverse significant correlation between 
Job Dedication and Civil Virtue and at the same time, the direct significant correlation between Job Dedication and Loyalty. Those employees aim only at work in order to obtain material compensation. They don't have a strong connection to the workplace or their job duties. They don't see their job as a place to learn or gain experience. There is no real loyalty to work; it is a false loyalty because the employee is interested only in maintaining the job that provides him with financial reward.

Respondents in Civil Service Orientation cluster were characterized by the lowest factor of Loyalty among other cluster groups. The respondents in this cluster have an inverse significant correlation between Civil Virtue and Loyalty. For such employee, the satisfaction of the customer is above all. It is important to him that the customer is satisfied and less important is the good of the organization. Respondents in Career Orientation cluster were characterized by the highest indicator of Job Dedication and the lowest of Civil Virtue. Employees with Career orientation are ambitious people: they seek to reach a higher status, to receive power and influence. In contrast to Job Orientation cluster respondents, the correlation between Job Dedication and Loyalty is inverted and significant. Such employees are not loyal to the organization, but only to themselves. They will not think twice and agree to leave the organization in favour of a higher position in another organization.

In Calling Orientation cluster, the average values of all factors are higher than the average for the aggregate, and the average value of the Loyalty factor is higher than that of respondents from other cluster groups. There is a direct significant correlation between the factors of Job Dedication and Civil Virtue in this cluster, that is, the larger the value Job Dedication, the higher the value of Civil Virtue. Employees with Calling Orientation are satisfied with their professional life, do everything to improve the organization, ready to learn others, to solve customers' problems and transfer knowledge.

A correlation-regression analysis that was used in the study identified strength, nature, and significance of the relationships between OLC and OCB factors. The result of the regression analyses supports the hypothesis, which states that the OLC had a significant effect in stimulating OCB and positively related to OCB. It means that an organizational learning process enables employees at all levels to improve their performance, thereby helping to achieve the organization's goals.

The research found a significant relationship between the type of organization according to its learning culture and the behaviour of its employees. A significant link was found between OLC and OCB was not previously examined according to the proposed Model.

Most employees who discover a type of Job Orientation behaviour are found in archaic organizations as an Outdated Organization. Their numbers are decreasing but still constitute the highest percentage, in Organizations in Conflict. Career Orientation is also seen in large numbers in these organizations, respectively. Most employees who belong to Calling Orientation behaviour come from Learning Organizations or Organizations in Evolution. Civil Service Orientation behaviour is also typical for organizations from a type of Learning Organizations or Organizations in Evolution but in lower percentages. The employees who discover Calling Orientation behaviour come mainly from organizations that are aware of a high organizational learning culture. In these organizations, employees care about the organization, their level of service, dedication, and loyalty to the organization is high.

Demographic variables (e.g., employee time, gender, education level) were not found to be related to OLC and OCB. There is no statistically significant effect of geographical location, type of local authority or size on a type of OCB or OLC orientation group. Only one finding was statistically significant: the respondents with Civil Service Orientation and Calling Orientation have average age higher than a Job and Career Orientation.

\section{Conclusions}

The proposed methodology provides an understanding of the relationships between OLC and aspects of OCB behaviour that invaluable to managers and leaders for increasing organizational profitability, productivity, employees' involvement and service quality by creating OCB behaviour. This methodology can be used to systematically assess and identify organizational affiliation in terms of organizational learning culture and employees' behaviour in accordance with their orientation to perform their work to develop a better strategy for successful implementation change initiatives. 
Methodology helps build an action plan and take steps toward becoming a Learning Organization that targets OCB behaviour. The suggestion of this study is that, given the OLC levels revealed in the sample, managers should implement an improvement in training and create real-time for specific courses to promote OLC and in this way OCB.

\section{Bibliography}

1. Ababneh R. (2013). Antecedents and outcomes of career development in Jordanian public sector. Journal of Emerging Trends in Economics and Management Sciences, 4(4), 417-426. Retrieved from http://jetems.scholarlinkresearch.com/articles/Antecedents\%20and\%20Outcomes.pdf

2. Bateman T.S., Organ D.W. (1983). Job satisfaction and the good soldier: The relationship between affect and employee citizenship. Academy of Management Journal, 26(4), 587-595. doi: $10.5465 / 255908$

3. Berg J.M., Grant A.M., Johnson V. (2010). When callings are calling: Crafting work and leisure in pursuit of unanswered occupational callings. Organization Science, 21(5), 973-994. doi: $10.1287 /$ orsc. 1090.0497

4. Eisenberg A. (2019). The interrelation between Organizational Learning Culture and Organizational Citizenship Behaviour in local government in Israel. (Doctoral dissertation, Daugavpils University, Daugavpils) Retrieved from https://du.lv/wp-content/uploads/2019/05/Dissertation_21_03_19.pdf

5. Eisenberg A., Davidova J., Kokina I. (2018). The interrelation between organizational learning culture and organizational citizenship behaviour. In V. Dislere (Ed.), Proceedings of the International Scientific Conference Rural Environment. Education. Personality (REEP), 11. Jelgava: Latvia University of Life Sciences and Technologies, 354-363. doi: 10.22616/REEP.2018.043

6. Eisenberg A., Ignatjeva S. (2018). Adaptation of the organizational citizenship behaviour (OCB) dimension methodology in the Israeli local authorities' context. In M. N̦esterova (Ed.), Social Sciences Bulletin, 26(1), 76-94. Retrieved from http://humanitiessocial.lv/wpcontent/uploads/2018/11/Socialo_Zinatnu_Vestnesis_2018_1.pdf

7. Eisenberg A., Ignatjeva S., Iliško D., Rauckiene-Michaelsson A. (2018). Adaptation of the organizational learning culture (OLC) dimension methodology in the Israeli local authorities' context. Discourse and Communication for Sustainable Education Journal, 9(1), 50-63. doi: 10.2478/dcse-2018-0004

8. Islam T., Aamir M., Khan S.R., Ahmad U.N.U. (2013). Organizational learning culture, social exchange relations and multi foci citizenship behaviours: A Literature survey approach. World Journal of Management and Behavioural Studies, 1(1), 6-13. Retrieved from https://idosi.org/wjmbs/1(1)13/2.pdf

9. Jo S.J., Joo B.K. (2011). Knowledge sharing: The influences of learning organization culture, organizational commitment and organizational citizenship behaviours. Journal of Leadership and Organizational Culture, 18(3), 353-364. doi: 10.1177/1548051811405208

10. Joo B.K., Yang B. (2007). The Impact of Contextual and Personal Characteristics on Employee Creativity. Philadelphia: Academy of Management.

11. Kaya A. (2015). The relationship between spiritual leadership and organizational citizenship behaviours: A research on school principals' behaviours. Educational Sciences: Theory \& practice, 15(3), 597-606. doi: 10.12738/estp.2015.3.1988

12. Kim K., Watkins K.E., Lu Z. (2017). The impact of a learning organization on performance: Focusing on knowledge performance and financial performance. European Journal of Training and Development, 41(2), 177-193. doi: 10.1108/EJTD-01-2016-0003

13. Kleiner A., Smith B., Roberts C. Senge P.M., Ross R. (1994). The Fifth Discipline Fieldbook: Strategies and tools for building a learning organization. New York: Currency, Doubleday.

14. Lai J.Y.M., Lam L.W., Lam S.S.K. (2013). Organizational citizenship behaviour in work groups: A team cultural perspective. Journal of Organization Behaviour, 34(7), 1039-1056. doi: $10.1002 /$ job. 1840

15. López S.P., Peón J.M.M., Ordás C.J.V. (2005). Organizational learning as a determining factor in business performance. The Learning Organization, 12(3), 227-245. doi: 10.1108/09696470510592494

16. Marsick V.J., Watkins K.E. (2003). Demonstrating the value of an organization's learning culture: The dimension of the learning organizational questionnaire. Advances in Developing Human Resources, 5(2), 132-151. doi: 10.1177/1523422303005002002

17. Moghadam M.N., Beheshtifar M., Darvishzade M.A. (2012). Organizational learning culture via creative climate. Science Series Data Report, 4(1), 14-20. Retrieved from http://www.flexmanager.ir/sites/default/files/download/Ssdr9c341.pdf 
18. Oplatka I. (2009). Organizational citizenship behaviour in teaching: The consequences for teachers, pupils and the school. International Journal of Educational Management, 23(5), 375-389. doi: 10.1108/09513540910970476

19. O'Reilly C.A., Chatman J.A. (1996). Culture as social control: Corporations, cults, and commitment. In B.M. Staw, L.L. Cummings (Eds.), Research in Organizational Behaviour: An annual series of analytical essays and critical review, 18, 157-200.

20. Organ D.W. (1988). Organizational Citizenship Behaviour: The good soldier syndrome. Lexington: Lexington Books.

21. Organ D.W. (1990). The subtle significance of job satisfaction. Clinical Laboratory Management Review, 4(1), 94-98.

22. Organ D.W., Podsakoff P.M., MacKenzie S.B. (2006). Organizational Citizenship Behaviour: Its nature, antecedents and consequences. Thousand Oaks, CA: Sage.

23. Pedler M.J. (1996). The Learning Company: A strategy for sustainable development. England: McGrow-Hill.

24. Pickford H.C., Joy G. (2016). Organizational Citizenship Behaviours: Definitions and dimensions. Oxford: Saïd Business School. Retrieved from http://eureka.sbs.ox.ac.uk/6265/1/2016-31.pdf

25. Podsakoff P.M., Ahearne M., MacKenzie S.B. (1997). Organizational citizenship behaviour and the quantity and quality of work group performance. Journal of Applied Psychology, 82(2), 262-270. doi: 10.1037/0021-9010.82.2.262

26. Podsakoff P.M., Mackenzie S.B., Moorman R.H., Fetter R. (1990). Transformational leader behaviours and their effects on followers' trust in leader, satisfaction and organizational citizenship behaviour. The Leadership Quarterly, 1(2), 107-142. doi: 10.1016/1048-9843(90)90009-7

27. Qureshi H. (2015). A Study of Organizational Citizenship Behaviours (OCB) and its Antecedents in an Indian Police Agency. (Doctoral dissertation, University of Cincinnati, Ohio, USA). Retrieved from https://www.researchgate.net/publication/296639798_A_Study_of_Organizational_Citizenship_Beha viors_OCB_and_its_Antecedents_in_an_Indian_Police_Agency

28. Salas-Vallina A., Alegre J., Fernández R. (2016). Organizational learning capability and organizational citizenship behaviour in the health sector: Examining the role of happiness at work from a gender perspective. The International Journal of Health Planning and Management, 32(2), e137-e159. doi: 10.1002/hpm.2363

29. Sampe F. (2012). The Influence of Organizational Learning on Performance in Indonesian SMEs. ( $\mathrm{PhD}$ thesis, Southern Cross University, Lismore, NSW:). Retrieved from https://epubs.scu.edu.au/cgi/viewcontent.cgi?article=1362\&context=theses

30. Smith C.A., Organ D.W., Near J.P. (1983). Organizational citizenship behaviour: Its nature and antecedents. Journal of Applied Psychology, 68(4), 653-663. doi: 10.1037/0021-9010.68.4.653

31. Somech A., Drach-Zahavy A. (2004). Exploring organizational citizenship behaviour from an organizational perspective: The relationship between organizational learning and organizational citizenship behaviour. Journal of Occupational and Organizational Psychology, 77(3), 281-298. doi: 10.1348/0963179041752709

32. Uygur A., Koç H. (2010). Organizational loyalty and organizational commitment: An analysis in terms of political party organizations. İşletme Araştırmaları Dergisi, 2(4), 79-94. Retrieved from https://www.isarder.org/tr/2010cilt2no4/e55.pdf

33. Vigoda-Gadot E., Beeri I., Birman-Shemesh T., Somech A. (2007). Group-level organizational citizenship behaviour in the education system: A scale reconstruction and validation. Educational Administration Quarterly, 43(4), 462-493. doi: 10.1177/0013161X07299435

34. Watkins K.E., Marsick V.J. (Eds.). (2003). Make Learning Count! Diagnosing the learning culture in organizations. Thousand Oaks, CA: Sage.

35. Wayne S.J., Shore L.M., Liden R.C. (1997). Perceived organizational support and leader-member exchange: A social exchange perspective. Academy of Management Journal, 40(1), 82 - 111. doi: $10.5465 / 257021$

36. Wrzesniewski A., McCauley C.R., Rozin P., Schwartz B. (1997). Jobs, careers, and callings: People's relations to their work. Journal of Research in Personality, 31(1), 21-33. doi: 10.1006/jrpe.1997.2162

37. Yeung A.K., Ulrich D.O., Nason S.W., Von Glinow M.A. (1999). Organizational Learning Capability. New York: Oxford University Press. 